\title{
Phenotypic variability in patients with generalised resistance to thyroid hormone
}

Joachim Pohlenz, Stefan Wirth, Andreas Winterpacht, Heike Wemme, Bernhard Zabel, Winfried Schönberger

\begin{abstract}
Genetic linkage of generalised resistance to thyroid hormone (GRTH) to the human thyroid receptor beta 1 gene has been identified. To date 38 different mutations in several kindreds have been documented. We report on a family with GRTH displaying an adenine for guanine substitution at nucleotide 1234 resulting in a threonine for alanine substitution at codon 317 of exon 9. This mutation has been described for different phenotypes, suggesting that the heterogeneity in GRTH may be the result of multiple genetic factors.
\end{abstract}

(f Med Genet 1995;32:393-395)

Generalised resistance to thyroid hormone (GRTH) was first described by Refetoff $e t a l^{1}$ in 1967 and is characterised by raised circulating levels of thyroid hormone with normal or inappropriately raised levels of thyroid stimulating hormone (TSH) in serum. The clinical phenotype varies. Affected subjects may be asymptomatic and diagnosed incidentally or display symptoms like hyperactivity, short stature, mental retardation, or language abnormalities. In some patients an enlargement of the thyroid gland can be detected. ${ }^{2}$ Genetic linkage of GRTH to the human thyroid receptor $\beta 1$ gene (c-erbA $\beta 1$ gene) has been identified $^{3}$ and to date 38 different point mutations in several kindreds have been documented. ${ }^{4}$ In about $90 \%$, GRTH was inherited in an autosomal dominant manner. Almost all mutations are located in exons 9 or 10 in the hormone binding domain. ${ }^{4}$ Language abnormalities have been described associated with mutations in the $5^{\prime}$ region of the dimerisation subdomain of exon $9 .{ }^{5}$ We report on two children and their father in a family with GRTH. An adenine to guanine replacement was found at nucleotide 1234 for amino acid 317 resulting in a threonine for alanine substitution in the receptor protein. This mutation has previously been described in a 10 year old boy with GRTH who had significant articulation problems. ${ }^{6} \mathrm{Our}$ investigations in the affected family show that the clinical phenotype may be different in patients with the same mutation, because no language abnormalities were detected in any member of this family.

\section{Case report}

An 8 year old girl was admitted to our hospital with a goitre and raised thyroid hormone levels. Physical examination showed her to be a physically and mentally normally developed girl with a visible goitre. Ultrasound examination of the thyroid gland showed an enlargement of both thyroid lobes (left lobe $7 \cdot 1 \mathrm{ml}$, right lobe $9.3 \mathrm{ml}$ ). Laboratory results showed raised triiodothyronine (T3), thyroxine (T4), free T3, free $\mathrm{T} 4$, and thyroid stimulating hormone (TSH) levels. TSH response 30 minutes after application of thyrotropin releasing hormone (TRH) was exaggerated (table). Thyroid microsomal, thyroglobulin, and $\mathrm{TSH}$ receptor antibodies were negative. GRTH was diagnosed and treatment with L-thyroxine $125 \mu \mathrm{g}$ daily was started, causing a decrease in the basal TSH level after one month. Four months later, ultrasound showed a reduction in thyroid gland volume of about $40 \%$. The TSH response after TRH was normal at this time. Under continuous treatment with L-thyroxine in adapted doses of up to $200 \mu \mathrm{g}$ daily, TSH levels and the thyroid gland volume remained within the normal range.

The 32 year old physically and mentally normally developed father underwent a physical examination because of a visible goitre. An enlargement of the thyroid gland became clinically relevant for the first time at the age of 8 years. Treatment with thyroid hormone was begun in another hospital, but discontinued by the patient after a few months The enlargement of the thyroid gland increased and eight years later large parts of the thyroid gland were resected. Following the diagnosis of hyperthyroidism treatment with antithyroid drugs was started, but discontinued after a few months. At the time the patient presented in our clinic, the thyroid gland was again enlarged (left lobe $67 \mathrm{ml}$, right lobe $46.5 \mathrm{ml}$ ). T3, free $\mathrm{T} 3$, T4, free $\mathrm{T} 4$, basal TSH, and TSH response to TRH were raised (table). Treatment with L-thyroxine $225 \mu \mathrm{g}$ daily was started. Basal TSH, TSH response to TRH, and the volume of the thyroid gland decreased nine months later.

The 3 year 8 month old boy of the GRTH family was also examined. Physical findings were normal but ultrasound assessment showed a slightly enlarged thyroid gland (left lobe volume $3.6 \mathrm{ml}$, right lobe $3.1 \mathrm{ml}$ ). Laboratory results showed raised T3, free $\mathrm{T} 3$, T4, free $\mathrm{T} 4$, basal TSH levels, and an exaggerated TSH response to TRH (table). After treatment with 
Thyroid function tests in three affected members of a family with generalised resistance to thyroid hormone

\begin{tabular}{lcccl}
\hline Serum concentrations & Daughter & Father & Son & Normal range \\
\hline Before treatment with L-thyroxine & & & & \\
T3 (nmol/1) & $4 \cdot 9$ & $5 \cdot 0$ & $5 \cdot 1$ & $1 \cdot 2-2 \cdot 8$ \\
T4 (nmol/1) & 201 & 180 & 249 & $64-169$ \\
Free T3 (pmol/l) & 16 & 17 & 17 & $2 \cdot 5-8 \cdot 5$ \\
Free T4 (pmol/1) & 12 & 51 & 11 & $0-26$ \\
TSH basal (mU/l) & 84 & 56 & 66 & $6-28$ \\
TSH peak response to TRH & $3 \cdot 4$ & $3 \cdot 4$ & $2 \cdot 8$ & $1 \cdot 2-2 \cdot 8$ \\
Under treatment with L-thyroxine & 340 & 273 & 311 & $64-169$ \\
T3 (nmol/1) & 21 & 16 & 20 & $2 \cdot 5-8 \cdot 5$ \\
T4 (nmol/l) & 99 & 54 & 104 & $9-26$ \\
Free T3 (pmol/l) & 1 & 2 & 2 & $0 \cdot 1-4 \cdot 5$ \\
Free T4 (pmol/1) & 17 & 10 & 14 & $6-28$ \\
TSH basal (mU/l) & & & \\
TSH peak response to TRH & & &
\end{tabular}

$75 \mu \mathrm{g}$ L-thyroxine daily, basal TSH levels and thyroid volume decreased and TSH response to TRH became normal.

HORMONE ASSAYS AND MOLECULAR STUDIES T3, T4, free T3, free $\mathrm{T} 4$, and $\mathrm{TSH}$ were measured by radioimmunoassay (Baxter, Behring, Biermann, Kodak, Germany). DNA analysis was performed in each member of the affected family and in 10 unaffected, unrelated persons. Informed consent to participate in the genetic study was given by all subjects or their parents. DNA was extracted from leucocytes according to standard procedures. ${ }^{3}$ Previously described primers ${ }^{7}$ were synthesised using a DNA/RNA synthesiser (model 392, Applied Biosystems). PCR reaction consisted of $10 \times$ reaction buffer $(5 \mu \mathrm{l}), 1.25 \mathrm{mmol} \mathrm{dNTP}$ mix $(8 \mu \mathrm{l}), 1 \mu \mathrm{l} \mathrm{Taq}$ Polymerase, $25 \mathrm{pmol}$ of each primer, and $0.5 \mu \mathrm{g}$ DNA template in a total volume of $50 \mu \mathrm{l}$. After denaturation at $94^{\circ} \mathrm{C}$ for four minutes the amplification reaction was performed at $94^{\circ} \mathrm{C}$ for 30 seconds, $58^{\circ} \mathrm{C}$ for
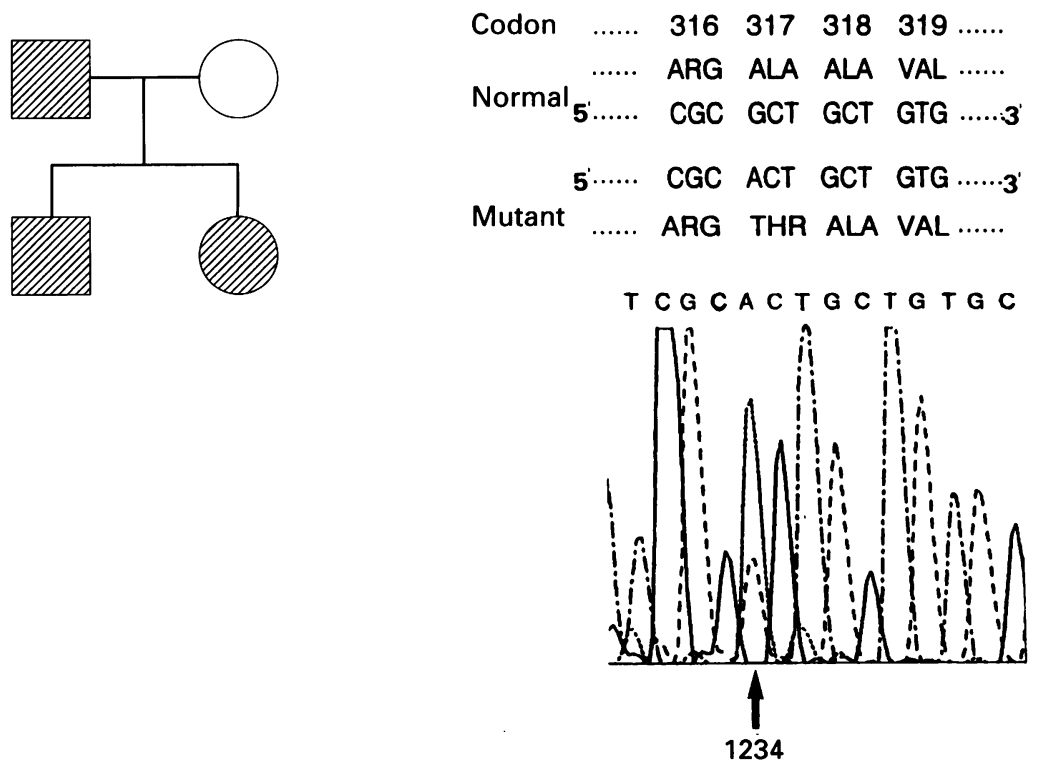

Family with GRTH. In three affected members (hatched symbols) a mutation from alanine to threonine in codon 317 was found. Automated fluorescence based sequencing of one patient is illustrated. The arrow indicates the substitution of a $G$ for an $A$ on nucleotide 1234 at codon 317. Each nucleotide is associated with a different line pattern in order to simplify the identification of abnormalities in the receptor protein. Since our patients with GRTH are heterozygous for the mutation, not only the dominating mutant $A$, but also a weak $G$ peak can be seen at position 1234 .
30 seconds, $72^{\circ} \mathrm{C}$ for 90 seconds, and repeated 29 times, with a final extension at $72^{\circ} \mathrm{C}$ for five minutes. After purification of PCR products direct automated fluorescence based sequencing on both strands was performed using equipment purchased from Applied Biosystems (Model 373 A). The biochemical evidence of thyroid hormone resistance in the patients is summarised in the table. DNA analysis showed a heterozygous adenine for guanine substitution at position 1234 in the father and the two children. This resulted in the replacement of normal alanine 317 with a threonine (A 317 $\mathrm{T}$ ) (figure) located in the $5^{\prime}$ region of the dimerisation subdomain of exon 9 in the receptor protein. A similar base abnormality was not detected either in the mother or in any of the tested unaffected subjects. Investigation of the remaining exons showed no further mutation in the patients.

\section{Discussion}

In GRTH, both the pituitary and the peripheral tissues are partially resistant to thyroid hormone. Raised TSH secretion and subsequently increased thyroid hormone production results. Administration of TRH causes a normal or exaggerated $\mathrm{TSH}$ response. After treatment with adequate amounts of thyroid hormone, TSH is suppressed. ${ }^{2}$ In the family reported here, one child displayed the clinical features of a goitre and raised thyroid hormone levels. After GRTH was diagnosed, we identified the father and also the brother as being affected (figure). DNA analysis showed a mutation from alanine to threonine in codon 317 of the human thyroid hormone receptor $\beta 1$ gene. An identical mutation was previously described by Parrilla et al. ${ }^{6}$ These authors reported on a 10 year old boy with GRTH who had a sporadic mutation and significant articulation problems. Parrilla $e t a l^{6}$ investigated the functional properties of the mutant receptor and observed an impaired $\mathrm{T} 3$ binding affinity compared to the wild type receptor. Regarding general language abnormalities in patients with GRTH, 12 further kindreds with GRTH were examined by Mixon et $a l .{ }^{5}$ They found that kindreds with mutations in exon 9 had significantly more language abnormalities than those with mutations in exon 10.5 We examined three affected members of two generations in one family and 
found the clinical phenotype to be different. No abnormalities in language development, articulation problems, or signs consistent with dyslexia were documented. Our observations indicate that the same mutation in GRTH may be associated with different phenotypes. An explanation for the heterogeneity of phenotypes might be the presence of various levels of expression of wild type and mutant receptors in each person and in each particular tissue, as postulated by Mixon et al, ${ }^{8}$ who found a markedly different expression of mutant and normal mRNA levels in two kindreds with GRTH. In contrast, Hayashi et $a l^{9}$ showed that differences between the functional impairment of the mutant thyroid receptor and the clinical manifestation of GRTH are not the result of quantitative differences in the expression of the normal and the mutant thyroid receptor gene. Thus, multiple genetic factors may play a role in the heterogeneity of GRTH. Weiss et $a l^{10}$ reported on a large kindred with GRTH within which the first degree relatives without a mutation in the thyroid receptor gene had significantly higher serum levels of thyroid hormone than genetically unrelated family members exposed to similar environmental conditions. The authors concluded that genetic variability of factors that contribute to the action of thyroid hormone may modulate the phenotype of GRTH. ${ }^{410}$ Further investigation of these factors and their role in thyroid hormone action is necessary to elucidate the phenotypic variability within and between kindreds with GRTH.

1 Refetoff S, DeWind LT, DeGroot LJ. Familial syndrome combining deaf-mutism, stippled epiphyses, goiter and abnormally high PBI: possible organ refractoriness to thyroid hormone. F Clin Endocrinol 1967;27:279-94.

2 MacDermott MT, Ridgway EC. Thyroid hormone resistance syndromes. Am ₹ Med 1993;94:424-32.

3 Usala SJ, Bale AE, Gesundheit N, et al. Tight linkage between the syndrome of generalized thyroid hormone resistance and the human c-erbA-beta gene. Mol Endocrinol 1988;2:1217-20.

4 Weiss RE, Weinberg $M$, Refetoff S. Identical mutations in unrelated families with generalized resistance to thyroid hormone occur in cytosine-guanine-rich areas of the thy roid hormone receptor beta gene. I Clin Invest 1993;91: 2408-15.

5 Mixon AJ, Parrilla R, Ransom SC, et al. Correlations of language abnormalities with localization of mutations in the $\beta$-thyroid hormone receptor in 13 kindreds with generalized resistance to thyroid hormone: identification of four new mutations. $\mathcal{F}$ Clin Endocrinol Metab 1992;75: 1039-45.

6 Parrilla R, Mixon AJ, McPherson JA, McClaskey JH, Weintraub BD. Characterisation of seven novel mutations of the c-erbA $\beta$ gene in unrelated kindreds with generalized thyroid hormone resistance. $\mathcal{F}$ Clin Invest 1991;88:212330 .

7 Sasaki S, Nakamura H, Tagami T, et al. Pituitary resistance to thyroid hormone associated with a base mutation in the hormone-binding domain of the human $3,5,3^{\prime}$-trithe hormone-binding domain of the human 3,5,3'tri-
iodothyronine receptor- $\beta$. F Clin Endocrinol Metab 1993; iodothyron $1254-8$.

8 Mixon AJ, Hauser P, Tennyson G, Renault JC, Bodenner DL, Weintraub BD. Differential expression of mutant and normal beta T3 receptor alleles in kindreds with and normal beta T3 receptor alleles in kindreds with
generalized resistance to thyroid hormone. 7 Clin Invest 1993;91:2296-300.

9 Hayashi Y, Janssen OE, Weiss RE, Murata Y, Seo H, Refetoff $S$. The relative expression of mutant and normal thyroid hormone receptor genes in patients with generalized resistance to thyroid hormone determined by estimation of their specific messenger ribonuleic acid products. $7 \mathrm{Clin}$ Endocrinol Metab 1993;76:64-9.

10 Weiss RE, Marcocci C, Bruno-Bossio G, Refetoff S. Multiple genetic factors in the heterogeneity of thyroid hormone resistance. $\mathcal{F}$ Clin Endocrinol Metab 1993;76:257-9. 